\title{
PENGGUNAAN APLIKASI CANVA UNTUK MEMBUAT KONTEN GAMBAR PADA MEDIA SOSIAL SEBAGAI UPAYA MEMPROMOSIKAN HASIL PRODUK UKM
}

\author{
Muhammad Sholeh"1), Rr. Yuliana Rachmawati ${ }^{1)}$, Erma Susanti1) \\ 1) Program Studi Informatika, Fakultas Teknologi Industri, Institut Sains \& Teknologi AKPRIND Yogyakarta \\ Corresponding author : Muhammad Sholeh \\ E-mail : muhash@akprind.ac.id
}

Diterima 23 September 2020, Direvisi 06 Oktober 2020, Disetujui 07 Oktober 2020

\begin{abstract}
ABSTRAK
Tujuan dari kegiatan ini adalah memberikan wawasan kepada para pelaku UMKM di Kecamatan Sedayu dalam menggunakan media sosial sebagai sarana promosi, terutama dalam membuat konten degan aplikasi Canva. Penggunaan media sosial tidak hanya memasang foto produk tetapi bagaimana mengemas konten produk tersebut menjadi menarik dan ada nilai tawar. Persoalan yang sering dialami pelaku usaha dalam menggunakan media sosial adalah membuat konten yang menarik dan mudah. Upaya untuk memberikan cara membuat konten yang mudah dan menarik adalah dengan menggunakan aplikasi yang menawarkan template-template. Salah satu aplikasi yang bisa digunakan adalah dengan menggunakan Canva. Dengan Canva, pelaku usaha dapat membuat konten dengan pilihan template yang sudah tersedia, membuat logo, poster, info grafis, newsletter, featured image blog, invoice, thumbnail Youtube serta desain kemasan. Dalam pelaksanaan pendampingan ini, pelaksanaan dilakukan dengan menggunakan metode diskusi untuk memetakan persoalan yang dihadapai pelaku UMKM tertanda alam penggunaan media sosial. Diskusi ini digunakan untuk memetakan sejauh mana persoalan dalam membuat konten serta dan penggunaan Canva serta dengan memberikan pelatihan dan pendampingan. Pendampingan kegiatan diikuti sekitar 10 peserta dari perwakilan pelaku usaha di kecamatan Sedayu Bantul. yang tergabung dalam Paguyuban UMKM Sedayu Bantul. Hasil akhir dari kegiatan ini peserta mempunyai gambaran penggunaan Canva.
\end{abstract}

Kata kunci: media social; konten; aplikasi; Canva.

\begin{abstract}
The purpose of this activity is to provide insight to MSME players in Sedayu District in using social media as a means of promotion, especially in creating content with the Canva application. The use of social media is not only about posting product photos but how to package product content to be attractive and have bargaining value. The problem that is often experienced by businesses in using social media is creating interesting and easy content. An effort to provide an easy and attractive way to create content is to use an application that offers templates. One application that can be used is to use Canva. With Canva, businesses can create content with a selection of templates that are already available, create logos, posters, graphic info, newsletters, featured image blogs, invoices, Youtube thumbnails and packaging designs. In the implementation of this assistance, the implementation is carried out by using the discussion method to map the problems faced by MSMEs that are marked by the use of social media. This discussion is used to map the extent of issues in content creation and use of Canva and by providing training and mentoring. 10 participants from representatives of business actors in the Sedayu sub-district, Bantul, participated in this event. who are members of the Sedayu Bantul UMKM Association. The end result of this activity participants have an overview of using Canva.
\end{abstract}

Keywords: social media; content; application; Canva.

\section{PENDAHULUAN}

Banyaknya pengguna media sosial tentunya membuka peluang bagi pelaku usaha dalam memasarkan produk. Peluang memasarkan memalu media sosial dapat dilakukan dengan membuat konten atau memasang hasil produk dalam media sosial. Penggunaan media sosial sebagai salah satu media pemasaran harus menjadi salah satu cara yang diantisipasi pelaku usaha. Dengan media sosial, pemasaran produk dapat dilakukan kapan saja dan jangkauan promosi semakin luas serta dapat melakukan interaksi antara penjual dengan calon pembeli. Media sosial adalah media online yang dimanfaatkan sebagai sarana pergaulan sesual secara online di internet. Di media sosial, proses interaksi dan komunikasi dapat dilakukan sesama 
penggunanya. Sesama pengguna dapat dapat saling berinteraksi, berkomunikasi, berbagi informasi dan kegiatan lainnya. Teknologi media sosial menggunakan teknologi berbasis internet atau aplikasi yang dapat mengubah suatu komunikasi ke dalam bentuk komunikasi yang dapat saling berinteraksi. Contoh media sosial yang populer dan banyak penggina di Indoensia diantaranya Facebook, YouTube, Blog, Twitter, Instagram (Mac Aditiawarman, 2019)

Menurut Utari (Utari, 2011), media sosial adalah sebagai sebuah media online dimana para penggunanya dapat dengan saling berpartisipasi. Berpartisipasi dalam arti pengguna dapat saling berinteraksi dengan mudah dalam berbagi informasi, menciptakan gambar dalam bentuk konten atau isi yang informasi yang akan disampaikan kepada orang lain, memberikan balasan komentar pada masukan yang disampaikan pengguna lain seta kominkasi lainnya yang ada dalam fasilitas media soaial. Semua dapat dilakukan dengan cepat dan tak terbatas. Publikasi menjadi hal yang sangat penting dalam mengenalkan ataupun mempromosikan potensi dari suatu daerah apapun itu, baik itu potensi sumber daya manusia maupun potensi wilayah yang ada, seperti potensi sumber daya alam. Dengan media sosial siapapun bisa mempublikasikan informasi apapun dengan sangat mudah dan dengan biaya yang sangat murah juga, terlebih dengan berkembangnya media sosial

Daya tarik promosi di media sosial diantaranya adalah konten promosi yang menarik dan mempunyai nilai tawar calon membeli untuk melihat konten dan akhirnya memutuskan untuk membeli. Menurut Kamus Besar Bahasa Indonesia (KBBI), "konten" diartikan sebagai suatu informasi yang tersedia melalui media atau produk elektronik. Dengan konten yang menarik pengguna media sosial dapat saling berinteraksi. Salah satu konten yang menarik untuk diposting ke media sosial adalah foto. Pengguna dapat memosting foto dengan gene bebas dengan kreativitas yang dimiliki. Foto menarik dalam media sosial adalah foto yang menjadi suatu hal yang baru, yang mengakibatkan banyak pengguna lain terinspirasi dengan konten/ foto tersebut (Ardipraditiya, 2020). Menurut Hanif (Hanif Mahaldi, 2018), hal lain yang perlu diperhatikan dalam membuat konten adalah target dari produk yang dituju. Produk sama tetapi sasaran berbeda isi konten bisa berbeda.

Penggunaan media sosial sebagai media promosi menjadi alternatif dalam melakukan promosi . Hal ini mengingat media sosial mudah diakses dimana saja dan kapan saja. Promosi di media sosial merupakan promosi yang murah karena tidak berbayar dan jangkauan lebih luas. Jadi promosi melalui media sosial itu sangat efektif dikalangan anak muda (Purbohastuti, 2017). Peneliti lain, Puspitasari (Puspitarini \& Nuraeni, 2019), melakukan penelitian pada Happy Go Lucky house yang melakukan promosi melalui Instagram. Hal utama dalam promosi adalah membuat pesan yang persuasif yang efektif untuk menarik perhatian konsumen. Kesimpulan dari penelitian bahwa Happy Go Lucky house melakukan pemanfaatan Instagram dengan baik, dilihat dari kegiatan promosi yang dilakukan sangat beragam dan juga dapat memanfaatkan berbagai fitur yang tersedia. Penelitian lain yang mengupas media sosial sebagai media promosi diantaranya (Romadhan, 2017), (Vernia, 2017), (Widayati \& Augustinah, 2019), (Fauzi, 2016)

Penelitian lain yang berhubungan dengan aplikasi Canva dilakukan oleh Lucius (Leryan et al., 2018). Lucius menggunakan hasil Canva sebagai inovasi dalam membuat media presentasi dan sudah dipraktekkan pada mahasiswa pendidikan sejarah Universitas Sanata Dharma. Dengan adanya aplikasi Canva ini, para pengajar mata pelajaran Sejarah mampu mengaplikasikan pembelajaran sejarah secara mudah dan dapat mengikuti perkembangan teknologi.

Purwati (Purwati et al., 2019), dalam pelaksanaan pengabdian pada masyarakat memberikan pelatihan penggunaan aplikasi Canva pada Komunitas ibu profesional Banyumas Raya. Materi yang diberikan dalam pelatihan adalah pengenalan Canva yang digunakan dalam membuat konten serta keperluan lain seperti membuat flyer. Selain membuat konten, dalam pelatihan ini juga disampaikan penggunaan Canva untuk membuat infografis,sertifikat serta mendesain poster untuk promosi atau penyampaian informasi.

Pelaksanaan pengabdian pada masyarakat yang lain dilakukan oleh (Pratiwi et al., 2020). Dalam pelaksanaan ini, peserta adalah para guru. Dalam pelatihan ini diharapkan peserta pelatihan sudah bisa menggunakan aplikasi yang digunakan dalam desain termasuk dengan menggunakan Canva.

Tujuan dari kegiatan ini diantaranya memberikan wawasan kepada para pelaku UMKM dalam menggunakan media sosial dalm melakukan promosi serta membuat kontenkonten produk yang mempunyai daya tarik dan dapat dikerjakan dengan mudah.Pesert dari pendampingan kegiatan ini adlah perwakilan dari paguyuban UMKM di kecamatan Sedayu Bantul. 


\section{METODE}

Kegiatan yang dilakukan merupakan rangkaian kegiatan dari pelaksanaan penelitian yang diimplementasikan pada masyarakat. Kegiatan ini bertujuan agar para pelaku UMKM dapat mengoptimalkan dalam melakukan promosi melalui media sosial. Kegiatan diikuti perwakilan pelaku UMKM yang tergabung dalam Paguyuban UMKM di Kecamatan Sedayu Bantul dan dalam kegiatan awal ini diikuti 10 peserta.

Sebelum pelaksanaan kegiatan, untuk mengetahui permasalahan yang ada dilakukan diskusi dengan pihak Kecamatan dan salah satu pelaku UMKM. Hasil diskusi diantaranya penggunaan media sosial sebagai media promsi belum maksimal dan perlu adanya kegiatan pendampingan yang terkait media sosial. Tahapan pelaksanaan ada pada gambar 1.

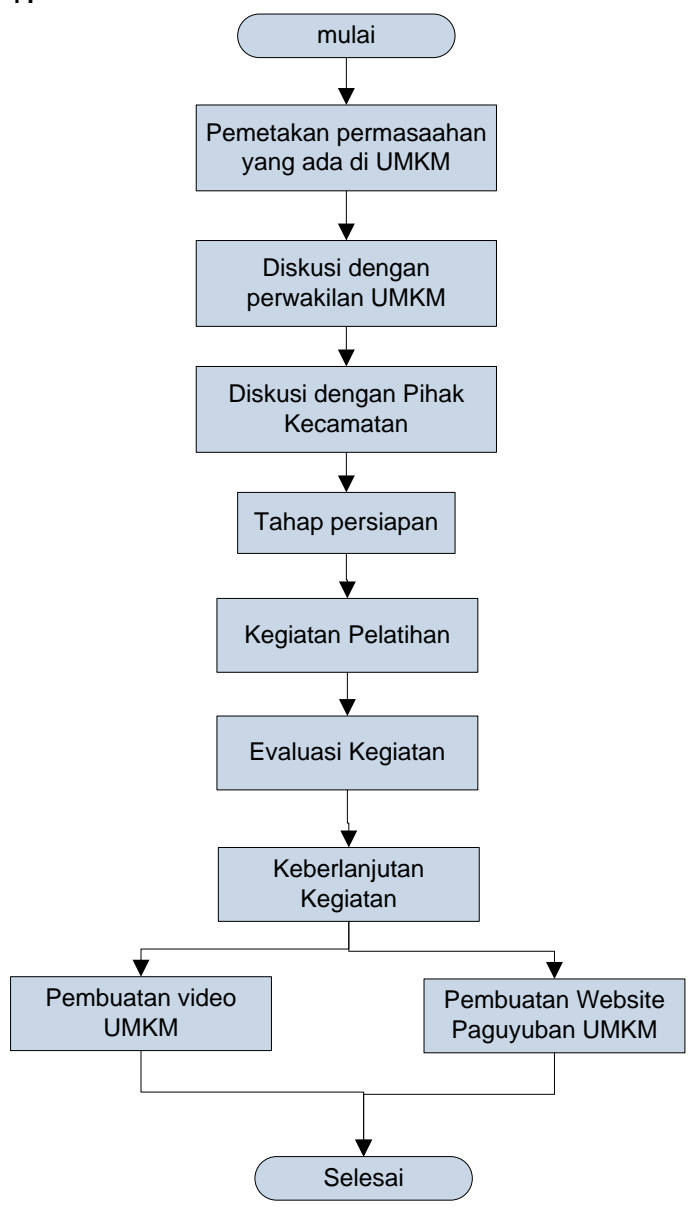

Gambar 1 Tahapan Pelaksanaan Kegiatan

\section{HASIL DAN PEMBAHASAN}

\section{Membuat konten dengan Canva}

Dalam melakukan promosi di media sosial, hal yang sangat penting adalah konten yang berisi promosi yang diposting di media sosial yang digunakan. Apapun bentuk promosi, foto atau konten menjadi salah satu daya Tarik konsumen untuk membaca atau menyimpan. Dalam membuat konten, kreativitas dan dukungan aplikasi yang mudah digunakan menjadi salah satu persoalan yang dihadapi para pelaku usaha dalam mempromosikan. Kekurangan mampuan dalam mendesain konten dan membuat konten yang menarik dapat diatasi dengan menggunakan aplikasiaplikasi yang gratis dan menawarkan berbagai template yang dapat digunakan. Salah satu aplikasi online yang gratis dan menawarkan banyak template adalah Canva. Canva adalah aplikasi yang dapat digunakan untuk melakukan desain grafis. Penggunaan aplikasi Canva dapat meningkatkan kreativitas dalam membuat desain poster, presentasi, dan konten visual lainnya. Dalam melakukan desain, aplikasi Canva menyediakan beragam foto yang dapat digunakan sebagai ilustrasi konten, konten dalam bentuk template sehingga dapat langsung digunakan, jenis huruf dan berbagai ilustrasi lainnya dalam menunjang kreativitas dalam membuat desain. Agar dapat menggunakan Canva, pengguna harus mendaftar sebagai anggota dan penggunaan Canva dilakukan secara online dengan laman www.canva.com. Gambar 2 merupakan halaman depan dari www.canva.com.

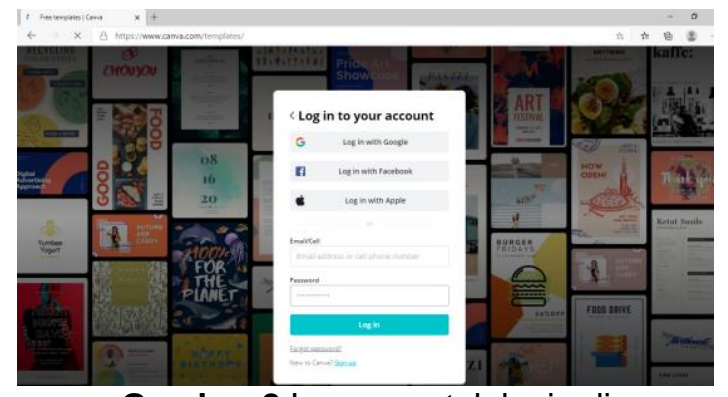

Gambar 2 Laman untuk login di www.canva.com

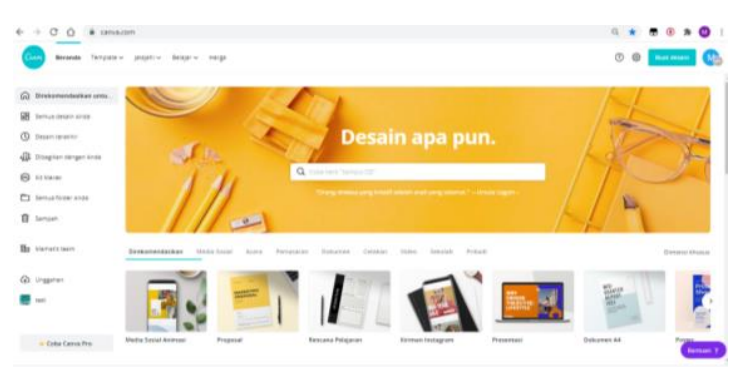

Gambar 3 Laman setelah login di www.canva.com

Dengan melakukan pendaftaran, pengguna dapat memanfaatkan fasilitas yang ada di Canva. Fasilitas yang ada diCanva tidak hanya berisi kumpulan template untuk desain konten tetapi ada fasilitas lain yang digunakan 
untuk membuat jenis huruf, animasi dan lainnya. Gambar 3, laman yang dapat digunakan setelah menjadi anggota di Canva

\section{Manfaat Canva}

Selain digunakan untuk mendesain konten di media sosial, Canva dapat digunakan untuk melakukan desain lain, seperti membuat logo, poster, banner iklan, dan lainnya. Desaindesain yang dapat dimanfaatkan diantaranya :

- Logo: Logo dapat digunakan sebagai sarana branding dari usaha yang dilakukan. Untuk mendesain logo, di Canva ada beberapa template yang sudah disediakan atau buat sendiri. Gambar 4 Contoh template yang sudah disediakan Canva.

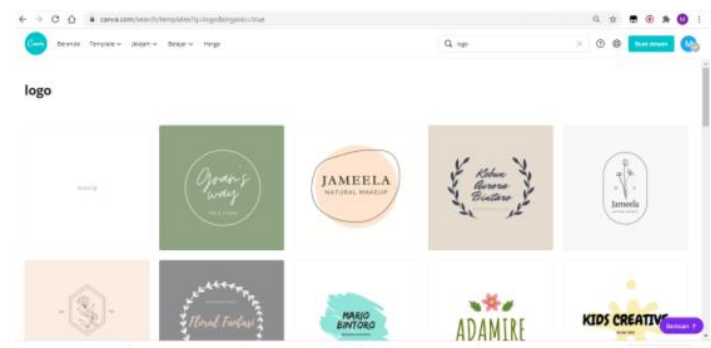

Gambar 4. Template untuk membuat logo

- Poster : Poster dapat digunakan untuk iklan produk, jasa dan lain-lain. Gambar 5, Contoh template untuk membuat poster

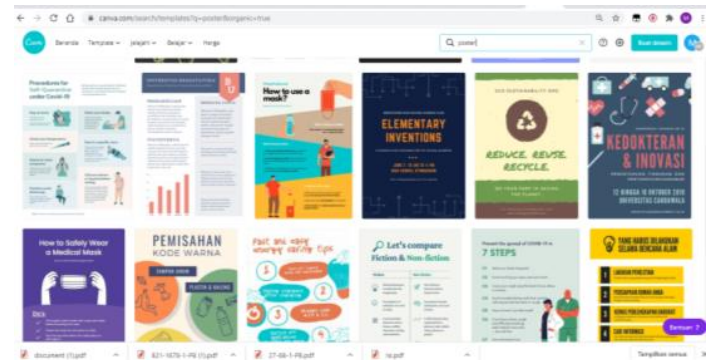

Gambar 5. Contoh template untuk membuat poster

- Banner Iklan: Banner iklan dapat digunakan untuk promosi dengan menggunakan website. Gambar 6, contoh template untuk membuat banner iklan

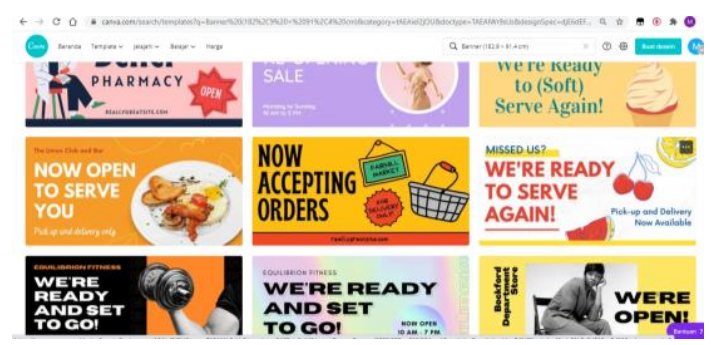

Gambar 6. Contoh template untuk membuat banner iklan
- Sertifikat : Template ini digunakan untuk membuat berbagai sertifikat. Gambar 7 Contoh template untuk membuat sertifikat

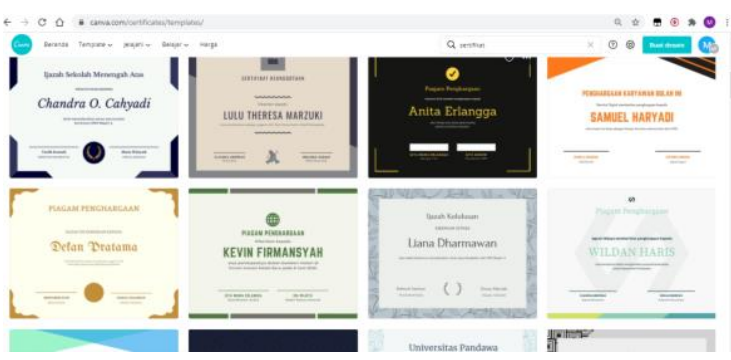

Gambar 7. Contoh template untuk membuat sertifikat

\section{Membuat konten di Canva}

Daya tarik di media sosial diantaranya adalah konten dan agar konten yang dibuat tidak hanya foto produk usaha, perlu adanya desain atau kemasan yang menarik. Membuat konten di Canva dapat dilakukan dengan memilih sosial. Gambar 8, tampilan pencarian dengan kata kunci media sosial. Hasil pencarian memunculkan berbagai template yang ada dan dari pilihan template yag digunakan, desain konten bisa diganti dengan foto dan narasi sesuai dengan keinginan. Gambar 9, contoh desain konten yang dipilih.
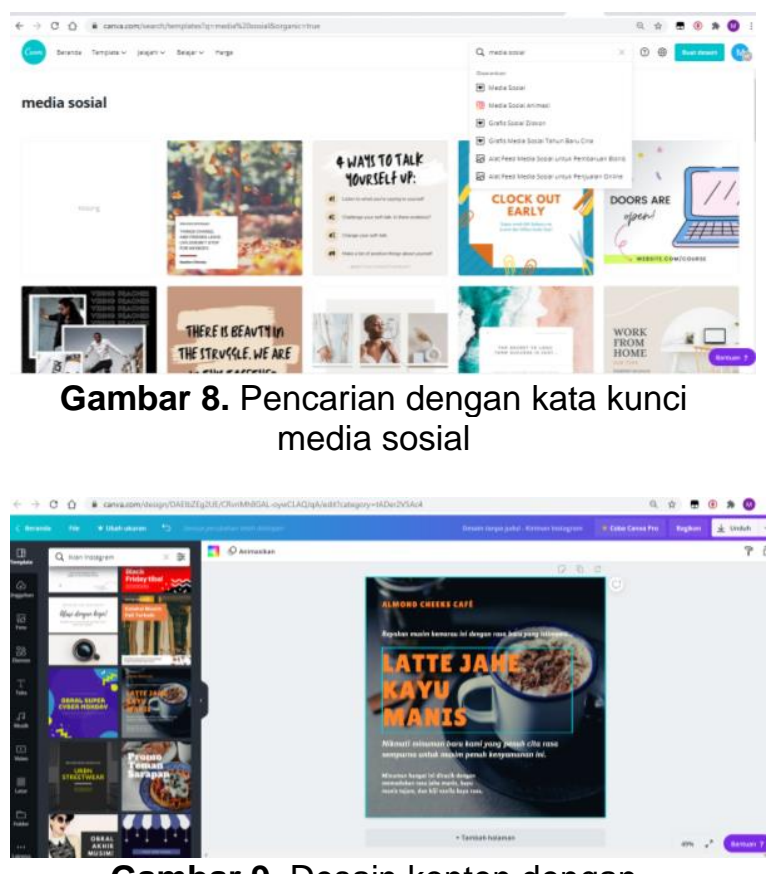

Gambar 9. Desain konten dengan menggunakan template

\section{Pelaksanaan Kegiatan}

Pelaksanaan kegiatan diawali dengan kuesioner yang diantaranya berisi pertanyaan apakah peserta yang mahir dalam membuat konten dan aplikasi yang pernah digunakan serta pertanyaan apakah pernah menggunakan Canva untuk mendesain konten. Jawaban dari 
pertanyaan tersebut, semua responden menjawab belum pernah membuat konten dengan aplikasi, proses promosi hanya memosting foto produk serta belum pernah menggunakan Canva. Gambar 10, pembukaan kegiatan oleh perwakilan dari kecamatan Sedayu dan gambar11, paparan dari nara sumber

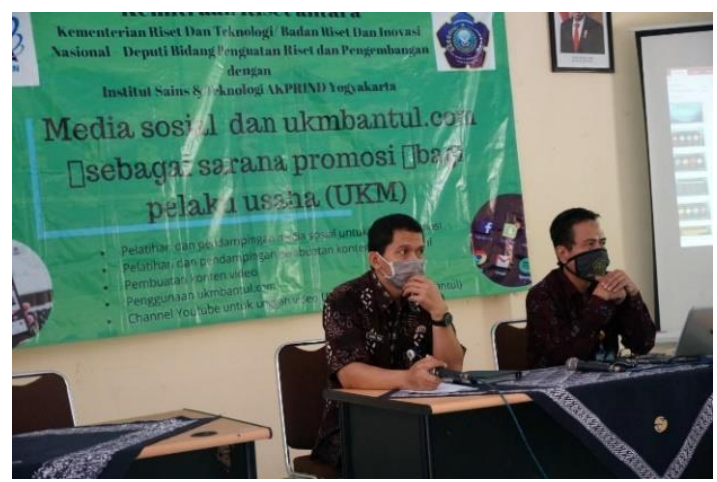

Gambar 10. Pembukaan kegiatan dari Kecamatan Sedayu

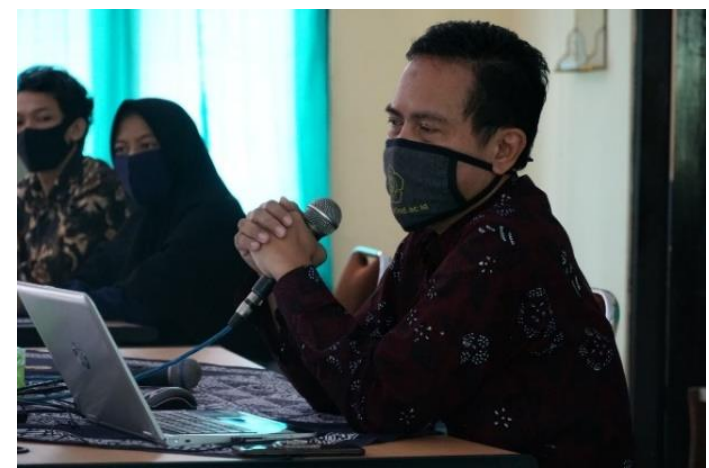

Gambar 11. Pemaparan dari nara sumber

Pelaksanaan sosialisasi dan pelatihan diantaranya bagaimana peserta dapat membuat konten di media sosial dengan mudah tetapi hasilnya menarik. Gambar 12, pemaparan materi Canva yang disampaikan narasumber

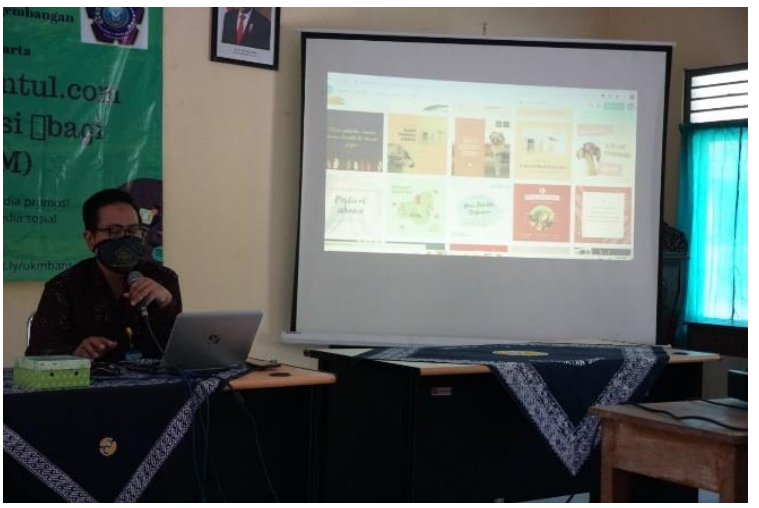

Gambar 12. Pemaparan materi Canva

Agar proses sosialisasi dapat berjalan dengan baik, diskusi dengan peserta menjadi sarana untuk mengetahui sejauh mana pemahaman terhadap kegiatan yang dilakukan. Gambar 13 dan gambar 14, suasana dalam pelaksanaan sosialisasi dan pelatihan.

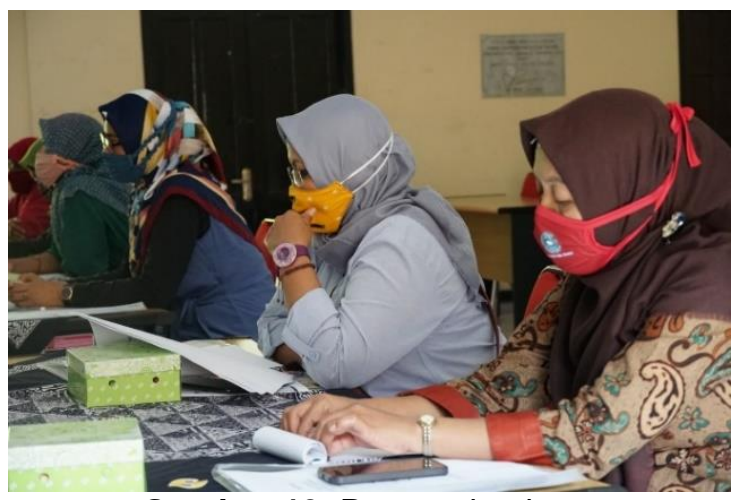

Gambar 13. Peserta kegiatan

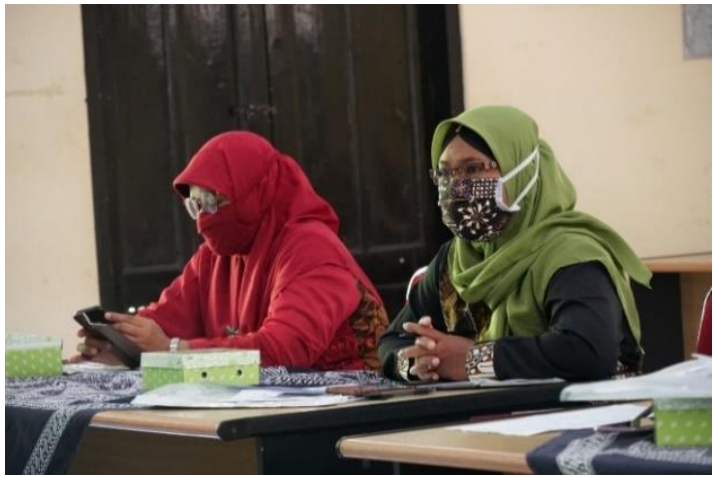

Gambar 14. Diskusi dengan peserta

\section{SIMPULAN DAN SARAN}

Konten menjadi salah satu faktor terpenting dalam pengelolaan promosi di media sosial. Kesulitan bagi pelaku usaha dalam membuat konten yang menarik dapat diatasi dengan menggunakan aplikasi yang menawarkan banyak template. Dengan banyaknya template, pengguna tinggal memilih template yang digunakan tanpa melakukan desain dari awal. Template yang dipilih dilakukan modifikasi dengan gambar dan narasi sesuai yang diinginkan.

Salah satu aplikasi yang dapat digunakan secara mudah dan banyak template adalah Canva. Canva merupakan aplikasi yang bersifat online dengan laman www. canva.com. Dalam sosialisasi ini peserta mendapatkan gambaran bagaimana membuat konten dengan mudah sehingga konten yang digunakan sebagai sarana promosi mempunyai day tawar yang menarik.

\section{UCAPAN TERIMAKASIH}

Terima kasih penulis sampaikan kepada semua pihak yang telah mengizinkan dan membantu dalam pelaksanaan kegiatan ini. Kegiatan ini merupakan rangkaian dari riset yang mendapatkan pendanaan dari Deputi 
Bidang Penguatan Riset dan Pengembangan Kementerian Riset dan Teknologi/ Badan Riset dan Inovasi Nasional tahun 2020. Ucapan terima kasih juga kami sampaikan pada Dinas Komunikasi dan Informatika kabupaten Bantul yang telah memberikan kesempatan kepada tim IST AKPRIND untuk memberikan pendampingan serta Kecamatan Sedayu yang telah memberikan fasilitas dalam kegiatan pendampingan ini.

\section{DAFTAR RUJUKAN}

Ardipraditiya, F. H. (2020). Peradaban Media Sosial di Era Industri 4.0. Inteligensia Media (Intrans Publishing Group).

Fauzi, viny putri. (2016). Pemanfaatan Instagram sebagai Social Media Marketing Er-corner Boutique dalam Membangun Brand Awareness di Kota Pekanbaru. Jom Fisip, 3(Februari), 115.

Hanif Mahaldi. (2018). Content Marketing Untuk Pemula. ebooku.id.

Leryan, L. P. A., Damringtyas, C. P., Hutomo, M. P., \& Printina, B. I. (2018). the Use of Canva Application As an Innovative Presentation Media Learning History. Prosiding Seminar Nasional FKIP 2018, 190-203. https://doi.org/10.24071/snfkip.2018.20

Mac Aditiawarman, R. (2019). Hoax dan Hate Speech di Dunia Maya. Lembaga Kajian Aset Budaya Indonesia Tonggak Tuo.

Pratiwi, D., Santoso, G. B., Mardianto, I., Sediyono, A., \& Rochman, A. (2020). Pengelolaan Konten Web Menggunakan Wordpress, Canva dan Photoshop untuk Guru-Guru Wilayah Jakarta Web Content Management Using Wordpress , Canva and Photoshop for Teachers of the Jakarta Region. Jurnal Ilmiah Pengabdian Pada Masyarakat, 2(1), 11-15.

Purbohastuti, A. . (2017). EFEKTIVITAS MEDIA SOSIAL SEBAGAI MEDIA PROMOSI Arum. Tirtayasa Ekonomika, 12(2), 212-231.

Purwati, Y., Perdanawanti, L., Informatika, P. T., Canva, A., \& Profesional, I. (2019). PELATIHAN DESAIN MENGGUNAKAN APLIKASI CANVA. Jurnal Pengabdian Mitra Masyarakat (JPMM) Vol., 1(1), 42-51.

Puspitarini, D. S., \& Nuraeni, R. (2019). Pemanfaatan Media Sosial Sebagai Media Promosi. Jurnal Common, 3(1), 71-80.

https://doi.org/10.34010/common.v3i1. 1950
Romadhan, M. I. (2017). Media Sosial Sebagai Sarana Promosi Potensi Desa. Jurnal Pengabdian LPPM Untag Surabaya, 2(2), 84-93.

Utari, P. (2011). Komunikasi 2.0 Teoritisasi dan Implikasi. Aspikom.

Vernia, D. M. (2017). Optimalisasi Media Sosial Sebagai Sarana Promosi Bisnis Online Bagi lbu Rumah Tangga Untuk Meningkatkan Perekonomian Keluarga. UTILITY: Jurnal IImiah Pendidikan Dan Ekonomi, 1(2), 105-118.

Widayati, W., \& Augustinah, F. (2019). Pemanfaatan Media Sosial Sebagai Sarana Promosi Makanan Ringan Kripik Singkong $\mathrm{Di}$ Kabupaten Sampang. DIALEKTIKA: Jurnal Ekonomi Dan IImu Sosial, 4(2), 1-20. https://doi.org/10.36636/dialektika.v4i2. 345 
Volume 4, Nomor 1, November 2020.

p-ISSN : 2614-5251

e-ISSN : 2614-526X 